\section{What can little Europe do?}

\section{Scientists must engage with the European Union's redesign of its research programmes to shore up the continent's competitive position.}

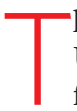
he research component of the European Union (EU) budget - known as the framework programme, now in its seventh iteration (FP7) - has experienced only incremental change each time the union has set its budget. The outcome is a set of activities, under FP7, of limited strategic impact.

This year will see researchers and policymakers begin to shape FP8, and it is abundantly clear that the steady-as-she-goes approach won't do this time around.

In the coming months, researchers must press home the things they need most from FP8: more effective 'joint programming' between member states, less onerous bureaucratic demands on project participants and expansion of the programme's funding agency, the European Research Council (ERC).

The EU has failed to meet, or even approach, its primary research-policy target, set out in 2002 , to increase investment in research and development (R\&D) to 3\% of gross domestic product (GDP). This measure of research intensity is still stuck where it was in 2002, at $1.9 \%$. This is unsurprising, perhaps, as it is dominated by the R\&D activities of industry, and so sits outside the direct control of politicians.

But the extent to which this is a political failure is underlined by the performance of China. There, R\&D investment surged from $0.7 \%$ of GDP in 1998 to $1.5 \%$ by 2008 , according to the Organisation for Economic Co-operation and Development in Paris. The growth comes from strong public investment, backed up by the actions of powerful and globally ambitious industrial companies. The United States has now pledged to up its performance, with President Barack Obama last April copying Europe's 3\% target, without specifying a date when it should be reached.

The battle between the United States and China for research pre-eminence - and the industrial and military strength that is assumed to follow from it - puts Europe's puny efforts somewhat in the shade. Last month, for example, one prominent European was planning to call his talk at the annual meeting of the American Association for the Advancement of Science in San Diego, California, 'What can little Europe do?' (A commission official dissuaded him.)

Europe's new research commissioner, Ireland's Máire Geoghegan-Quinn, took her first stab at answering that rhetorical question in Brussels on 5 March. In a talk to the Lisbon Council, a European think tank, she pledged to "refocus research and innovation policy" on five 'grand challenges' - energy, climate change, food security, health and ageing. This focus is supposed to excite the public and clarify research outcomes. Critics fear, however, that it will give politicians more control over what researchers do under the framework programme.

Other priorities for FP8, which is expected to run from 2014 until 2020, include support for infrastructure projects and for the expansion of the ERC - currently the star in the framework firmament.

Another major thrust of FP8 will probably be the rapid expansion of 'joint programming. This typically opaque phrase describes the alignment of research activities in the $27 \mathrm{EU}$ member states - which between them account for $95 \%$ of publicly funded research in Europe - with each other, and with the programmes of the European Commission. Joint programming gets fiercely independent national agencies to work together. A prototype for such collaboration is a project on Alzheimer's disease that involves, among others, INSERM in France, the German federal research ministry and the UK Medical Research Council. But fragmentation remains the norm.

\section{The bigger picture}

A key question to be addressed this year and next is how fast new ventures, such as joint programming and an expanded ERC, can be built up. Another is whether these will grow at the expense of the 'traditional' part of the framework programme - applied research projects with partners in at least three member states. This currently consumes two-thirds of the programme's $€ 7$-billion (US\$10-billion) annual budget.

Research leaders in all member states now agree that a European Research Area, across which scientists can move and collaborate freely,

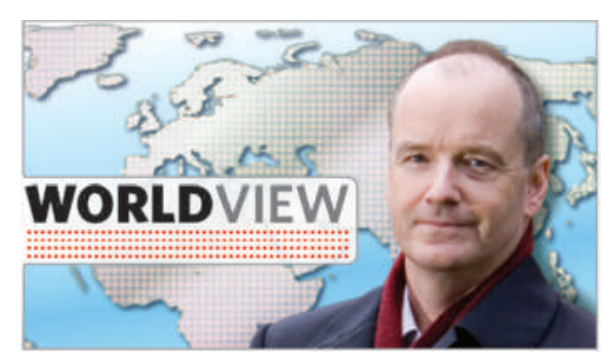

offers the best hope of competing with China and the United States. Behind the scenes, they are preparing to look far beyond FP8 and set objectives that would transform Europe's research landscape by 2030 . This would include the tripling of the share of the EU budget devoted to research (from $4 \%$ to $12 \%$ ) and the adoption of a more daring target for R\&D to reach $5 \%$ of GDP. (Japan is already touching $4 \%$.) The plan, which is being prepared for submission at the highest levels, also sets ambitious objectives for other areas of public policy related to science, from mobility and education to patenting and venture capital.

The hopes of these leaders are raised by the early success of the ERC in establishing its awards as the most prestigious in European science, and the high priority being given to research in the EU leadership's public pronouncements. Research and innovation take pride of place in the economic strategy document, Europe 2020, released by EU president José Barroso on $3 \mathrm{March}$, and there are plans for the heads of state to discuss research and innovation at the Autumn European Council meeting in September.

At the same time, optimism is challenged by niggling worries. Some doubt that Barroso will appoint a really prominent, independently minded chief scientific adviser, as he promised to do last September. They also fear that the European Commission will struggle to find a genuine star to accept the new director's post at the ERC.

Frustration continues to simmer over the paperwork and strenuous auditing requirements of the framework programme. Some 7,000 researchers have now signed an online petition (www.trust-researchers.eu) calling for an auditing regime "based on trust and responsible partnering". Their protest articulates a serious push to reform the programme's financial rules.

The petition is also a departure from researchers' customary forbearance of maladministered EU programmes. European science would benefit greatly if as many researchers as possible make waves about what they would like to see in the next EU budget. Rival beneficiaries of it, such as farmers and business lobby groups, will certainly be doing so. The ERC should be seen as a beachhead onto fresh territory, where EU awards become hallmarks of excellence. The current economic crisis gives the scientific community a chance - perhaps its last chance - to build on that, and to help ensure that little Europe doesn't slide into irrelevance.

Colin Macilwain is based in the United Kingdom.

e-mail: cfmworldview@gmail.com

See go.nature.com/ILx8PC for more columns. 